Aleksego I Komnena. Książkę Filipa van Trichta można uznać za kolejne interesujące spojrzenie historiografii zachodniej na sprawy Cesarstwa Łacińskiego. Spojrzenie jest ożywcze, nowe, ale bez odniesień do zdania historiografii krajów bałkańskich, tak jak gdyby ona w ogóle nie istniała. Autor dostrzegł wiele problemów, po części ignorowanych lub mniej eksponowanych dotąd. Wnioski na ogół są ciekawe, choć niekoniecznie odkrywcze.

Zdzistaw Pentek

Asymetryczne Balkany: dzialania asymetryczne, militarne i polityka bezpieczeństwa na Pólwyspie Balkańskim w XX i XXI wieku: materialy i studia, red. Danuta Gibas-Krzak, Wydawnictwo im. Stanisława Podobińskiego Akademii im. Jana Długosza, Częstochowa, 2015, ss. 391.

Celem recenzowanej monografii jest przedstawienie historycznych i współczesnych doświadczeń państw oraz społeczeństw rejonu bałkańskiego przez pryzmat konfliktów i działań asymetrycznych. Uwzględniony w pracy kontekst regionalny ma szczególne znaczenie, ponieważ w sensie odniesień geopolitycznych Bałkany zawsze charakteryzowały się nagromadzeniem czynników wymykających się tradycyjnej typologii konfliktów zbrojnych. Biorąc pod uwagę przeszłość regionu należy zauważyć, że tamtejsze konflikty społeczno-polityczne czy militarne są determinowane zarówno przez interesy miejscowych państw oraz mocarstw, jak i powiązania wyrastające ze zróżnicowanej, nierzadko niejednoznacznej charakterystyki etniczno-kulturowej. Tymczasem pojęcie zagrożenia asymetrycznego, które zyskało na popularności w ostatnim dziesięcioleciu w wyniku nasilenia terroryzmu międzynarodowego, utożsamiane jest właśnie z konfliktem między stronami o odmiennych typach organizacji, sposobach myślenia czy działania. Ponieważ w obecnych czasach zjawisko to uznaje się za jeden $\mathrm{z}$ ważniejszych problemów bezpieczeństwa międzynarodowego oraz wewnętrznego, temat recenzowanej monografii należy uznać za ważny i bardzo aktualny.

Na pracę składają się teksty związane z bardzo zróżnicowaną problematyką, o różnym stopniu szczegółowości. Autorzy nawiązują do poszczególnych zjawisk, utożsamianych z pojęciem konfliktu asymetrycznego, takich jak terroryzm międzynarodowy, transnarodowa przestępczość zorganizowana czy działania partyzanckie. Obok kwestii stricte historycznych, powiązanych z rozważaniami na temat relacji zimnowojennych i rozpadu socjalistycznej Jugosławii, zasygnalizowano zagadnienia dotyczące procesów kształtowania się współczesnych powiązań, odnoszących się do przestępczości zorganizowanej, migracji czy systemu bezpieczeństwa wewnętrznego w państwach regionu.

Redaktor monografii przyjęła uzasadnione założenie, że w kompozycji monografii powinny przeplatać się rozważania o charakterze interdyscyplinarnym, bez czego 
niemożliwa jest wyczerpująca charakterystyka fenomenu zjawisk asymetrycznych. Autorzy poszczególnych części pracy reprezentują takie dyscypliny naukowe, jak politologia, nauki o obronności, historia, antropologia kulturowa. W większości są związani z polskimi instytucjami naukowymi (w monografii znalazło się dziewięć tekstów polskojęzycznych, cztery anglojęzyczne i cztery w językach południowosłowiańskich). Decyzję, aby refleksję naukową oprzeć na długiej osi czasu, od końca II wojny światowej po dzień dzisiejszy, należy uzasadnić tym, że nawiązania i doświadczenia historyczne mają olbrzymi wpływ na współczesną percepcję relacji dotyczących stanu bezpieczeństwa na Bałkanach. Pewne wątpliwości dotyczą jednak tytułu monografii, który nie do końca odpowiada jej zawartości. W zasadzie poza jednym artykułem, przywołującym charakterystykę wojny domowej w Grecji, recenzowana praca odnosi się do państw umieszczanych obecnie w regionie bądź subregionie o nazwie Bałkany Zachodnie, które zresztą także nie są traktowane równorzędnie. W monografii widać wyraźną przewagę rozważań o problematyce chorwackiej, bośniackiej i serbskiej. Bez wątpienia wynika to z doboru autorów poszczególnych części pracy, którzy przeważnie reprezentują chorwackie jednostki naukowe.

W monografii dominują teksty dotyczące spraw politycznych i militarnych, ale poruszana problematyka jest znacznie bardziej rozproszona tematycznie, co więcej charakteryzuje się ona zróżnicowanym poziomem ogólności pod względem merytorycznym. Przyjęcie jednolitego kryterium, porządkującego układ monografii, było trudnym wyzwaniem, z którego Redaktor pracy wybrnęła, przyjmując wyznaczniki chronologiczne i problemowe. I tak, rozprawę otwierają dwa opracowania o ogólniejszym charakterze. Pierwsze dotyczy metodologii badań nad stosunkami o charakterze asymetrycznym (Danuta Gibas-Krzak), drugie cywilizacyjno-kulturowych podstaw relacji asymetrycznych w kontekście bałkańskim, które na wyrost zostały określone w tytule mianem psychologicznych (Anna Zasuń). Trzy kolejne opracowania odnoszą się do okresu zimnowojennego. Analityczny tekst autorstwa i dotyczą ruchu antykomunistycznego w Chorwacji w latach 1945-1950 (Zdenko Radelić), działalności ruchu komunistycznego podczas greckiej wojny domowej (Sebastian Pięta) oraz koncepcji wojny specjalnej rozwijanej przez kręgi wojskowe i rządzące w socjalistycznej federacji jugosłowiańskiej (Andrzej Krzak, Małgorzata Kuś). Następnie mowa o procesach i wydarzeniach określających stan relacji wewnątrzregionalnych po upadku socjalistycznej Jugosławii, które są rozwijane w ramach dwóch osi problemowych. Pierwsza dotyczy studiów nad relacjami asymetrycznymi w Chorwacji i Bośni i Hercegowinie w latach 1991-1995. W poszczególnych artykułach opisano relacje instytucjonalno-militarne w obu republikach (Davor Marijan), przybliżono warunki funkcjonowania i organizację tzw. Serbskiej Republiki Krajiny (Nikica Barić) oraz przebieg konfliktu chorwacko-muzułmańskiego w Bośni i Hercegowinie (Ivo Lucić). Oddzielne studia poświęcono okolicznościom zamachu na sarajewski bazar Markalije (Merisa Karović) i udziałowi Rosjan w tzw. wojnie bośniackiej (Mateusz Żulczyk). W drugiej grupie problemowej umieścić należy rozważania na temat złożonej specyfiki problemów bezpieczeństwa wewnętrznego w krajach Bałkanów Zachodnich (Zoran Vučković, Ida Orzechowska), najwięcej miejsca zajmują jednak teksty odno- 
szące się do zagadnienia przestępczości zorganizowanej w kontekście rozważań politologicznych (Izabela Olek, Katarzyna Olczyk), procesów migracyjnych (Desirée Pangerc) oraz zjawiska fundamentalizmu islamskiego (Justyna Kędziora-Płachciak, Darko Trifunović, Ioannis Michaletos).

Ważne dla recenzowanej monografii jest wprowadzenie problemowe, w którym D. Gibas-Krzak kompetentnie przedstawiła dylematy dotyczące wieloaspektowego znaczenia pojęcia asymetryczności w stosunkach politycznych i konfliktach zbrojnych. Zwróciła ona uwagę na konieczność stosowania zróżnicowanych metod badawczych, które uwzględniają zarówno zewnętrzny, jak i wewnętrzny kontekst poszczególnych działań. Bez wątpienia, w monografii dominuje problematyka chorwacka, widoczna zwłaszcza w opracowaniach dotyczących poszczególnych wymiarów tzw. wojny jugosłowiańskiej z lat 1991-1995. Teksty odnoszące się do poszczególnych zagadnień w większości zawierają rzetelną dokumentację prezentowanych zdarzeń. Autorzy starają się tworzyć w miarę pełny obraz faktograficzny problemów, choć czasem pojawiają się tezy wymagające bardziej skrupulatnego opracowania ze względu na swoją niejednoznaczność oraz kontrowersyjność. Mowa chociażby o opinii, jakoby chorwaccy Serbowie z Krainy mieli dokonać w 1995 roku „samooczyszczenia" etnicznego, emigrując z Chorwacji w obliczu militarnego zwycięstwa sił chorwackich w ramach operacji wojskowej „Burza”. (str. 142). W tym przypadku należało odnieść się do rozbieżności w interpretacjach następstw wspomnianej operacji, które są formułowane głównie poza Chorwacją, nie tylko przez stronę serbską. Ciekawy materiał poglądowy dostarcza opracowanie dotyczące zamachu na sarajewskim placu targowym Markale. Autorka wykorzystuje sprawozdania przedstawicieli sił międzynarodowych oraz raporty z Międzynarodowego Trybunału Karnego dla byłej Jugosławii w Hadze. Jej studium ma cechy syntetyczności i konkretności. Z kolei opracowanie o jugosłowiańskiej koncepcji wojny specjalnej autorstwa Andrzeja Krzaka i Małgorzaty Kuś, prezentuje problematykę rzadko opisywaną w polskojęzycznej historiografii. Poprzez uwzględnienie kontekstu ideologicznego i etnicznego, Autorzy rzucają interesujące światło na motywacje i lęki ówczesnych kreatorów polityki jugosłowiańskiego bezpieczeństwa. Tekst jest analityczny, czytelnik otrzymuje studium z dobrze dobraną i usystematyzowaną faktografią. Interesujące są także uwagi Zorana Vučkovicia na temat relacji między ośrodkami władzy w Republice Serbii po obaleniu S. Miloševicia a środowiskami przestępczymi, które posiadały duże wpływy w serbskich służbach bezpieczeństwa i walnie przyczyniły się do pokojowego przełomu demokratycznego w Serbii w 2000 roku. Autor kompetentnie, analitycznie przedstawia polityczne tło zamachu na premiera Serbii Zorana Dzindzicia (2003), akcentując rolę ,agresywnych narzędzi” stosowanych przez uczestników tamtejszej walki politycznej. Za interesujące należy uznać również uwagi włoskiej badaczki Desirée Pangerc, która zbadała wpływ zjawisk migracyjnych na stabilność państw regionu Bałkany zachodnie. Odwołując się do własnych badań w tej kwestii, Autorka zwraca uwagę na sieć powiązań instytucjonalnych i pozainstytucjonalnych o charakterze wewnątrzpaństwowym oraz międzynarodowym, które tworzą warunki sprzyjające nielegalnej migracji. Pewien niedosyt 
pod względem kompletności ujęcia, a także rzetelności naukowej, przedstawiają natomiast niektóre opracowania traktujące o terroryzmie. Częściowo wynika to z faktu, że problematyka terroryzmu przedstawia duże wyzwanie dla refleksji naukowej, zwłaszcza w wydaniu młodych badaczy. W tym przypadku nie zawsze sprawdzają się tradycyjne narzędzia badawcze, problem dotyczy dostępu do źródeł informacji czy oceny ich wiarygodności. W opracowaniach polskojęzycznych zamieszczonych w monografii dużo miejsca zajmuje teoretyczna analiza zjawiska, przez co nie wnoszą one nic nowego w sprawach bałkańskich. Autorzy przywołują to, co napisano już w literaturze przedmiotu, głównie anglojęzycznej i opierają się na klarownej encyklopedycznej typologii. Bez wątpienia, ze sporym odzewem a może i polemiką spotka się studium autorstwa Darka Trifunovicia i Ioannisa Michaletosa, którzy podejmują próbę rekonstrukcji mapy powiązań przestępczych, składających się na tzw. sieć afgańsko-bośniacką, identyfikowaną m.in. z przemytem narkotyków z Azji środkowej do Europy zachodniej. W oparciu głównie o materiały prasowe i agencyjne Autorzy dochodzą do wniosku, że duży udział w tych koneksjach mają członkowie oddziałów złożonych z muzułmanów, walczących po stronie bośniackiej w wojnie z pierwszej połowy lat 90 . Ponadto zwracają oni uwagę na istniejące ich zdaniem powiązania między nacjonalizmem albańskim a terroryzmem inspirowanym przez islamski fundamentalizm. Tekst ma charakter przyczynkowy i nie można go uznać za pełnoprawne studium naukowe. Autorzy nie powołują się ani na poważną literaturę przedmiotu, ani na badania własne. Jest jednak wart zainteresowania $\mathrm{z}$ innego powodu. Należy go potraktować jako element ogólniejszej narracji, rozwijanej przez publicystykę polityczną w poszczególnych krajach bałkańskich (np. w Serbii), gdzie zwraca się uwagę na to, że na Bałkanach są rekrutowani i szkoleni islamscy terroryści, którzy przeprowadzają zamachy w Europie zachodniej i USA.

Obecność wielu problemów badawczych, a także ich zróżnicowanie pod względem szczegółowości i chronologii sprawia, że struktura monografii ma charakter otwarty. Autorzy poszczególnych opracowań z rozmaitym skutkiem starają się zwrócić uwagę na to, jak asymetryczne relacje polityczne i militarne odmieniły oblicze poszczególnych społeczeństw i państw oraz w jakim stopniu mogą zmieniać charakterystykę całego regionu. Opracowanie to nie dąży do ujęcia całości problemu, który zresztą jest niemożliwy do jednoznacznej charakterystyki ze względu na swoją wielopłaszczyznowość. Należy je raczej potraktować jako wkład w rozwój dyskusji naukowych nad istotą zagrożeń asymetrycznych nie tylko na współczesnych Bałkanach, ale i współczesnym świecie. Dokonując ogólnej oceny należy stwierdzić, że z recenzowanej monografii wyłania się interesujący, wielopłaszczyznowy obraz geopolityki regionu, zanurzonego w problemach wynikających z niezwykłej różnorodności w sferze interesów etnicznych, politycznych i militarnych. Recenzowaną monografia to dzieło interesujące, skłaniające do polemiki, a o to przecież chodzi we współczesnej nauce. Bez wątpienia, stworzony w niej obraz stanowi interesujący punkt wyjścia dla dalszych badań i dyskusji nad specyfiką regionu. 


\section{Macedonia: Land, Region, Borderland, Colloquia Balkanica vol. 2, Warszawa 2013, Wydawnictwo DiG, ss. 590.}

Macedonia, leżąca w środkowej części Bałkanów, to jedno z najmłodszych państw europejskich. Odgrywa ona ważną rolę w procesie politycznej stabilizacji Bałkanów, choć spokój w tym państwie nie został do końca osiągnięty. Uczeni zadają pytania jak sprawić, by kraj ten mógł w pełni używać swoją nazwę, uregulować stosunki z sąsiadami, spacyfikować wewnętrzne napięcia etniczne. Celem monografii pod redakcją Joanny Sujeckiej jest stworzenie pola dla refleksji nad tożsamością Macedonii postrzeganej jako region kontaktowy i graniczny zarazem, ukształtowany poprzez współistnienie i współzależność wielu tradycji oraz idei. Redaktorka monografii przyjęła założenie, że w kompozycji powinny przeplatać się rozważania natury historycznej, ideologicznej, etno-lingwistycznej bez których niemożliwa jest wyczerpująca charakterystyka kulturowego fenomenu Macedonii. Decyzja, by refleksję nad Macedonią oprzeć na długiej osi czasu, od starożytności po czasy współczesne jest w pełni uzasadniona ze względu na ważną rolę nawiązań, inspiracji historycznych w tożsamości ludów odwołujących się do tzw. spuścizny macedońskiej.

Monografia składa się z dwóch części uporządkowanych w układzie rzeczowym. W pierwszej części znalazło się przedstawienie ewolucji pojęcia Macedonia od starożytności do pierwszej połowy XX wieku. Proces ten prześledzono na podstawie badań historycznych, antropologicznych i literackich. Autorzy powiązali ewolucję pojęcia Macedonia z przemianami społeczno-politycznymi, kulturowymi, terytorialnymi dotyczącymi omawianego regionu. Ich rozważania mają charakter szczegółowy, odnoszą się do poszczególnych okresów historycznych, ale rozdziały tworzą konsekwentną i jednolitą całość pod względem chronologii oraz tematyki. I tak, Jacek Rzepka zajął się zagadnieniem macedońskiej tożsamości etnicznej w starożytności, Irena Stefoska przybliżyła najważniejsze aspekty związane ze średniowieczną historią regionu a Dragi. G’orgiev przeanalizował ewolucję percepcji nazwy Macedonia w okresie panowania osmańskiego. Taka konstrukcja rozdziału umożliwiła ukazanie długofalowego procesu przewartościowania terminu Macedonia w dziejach Europy południowo-wschodniej przy utrzymaniu dość drobiazgowego toku narracji. Interesująco przedstawia się również studium o percepcji pojęcia Macedonia przez słowiańskojęzyczne elity z Macedonii osmańskiej w XIX i XX wieku (J. Sujecka), zamykające pierwszą część monografii. Rozważania o wizjach narodowości i państwowości macedońskiej są punktem wyjścia dla opisu współczesnej problematyki macedońskiej, kształtowanej przez argumenty narodowe i geopolityczne.

Druga część monografii, zatytułowana Kontekst, stanowi zróżnicowaną merytorycznie charakterystykę macedońskiej specyfiki kulturowej, historycznej i etnicznej. Wycinkowy niekiedy charakter zawartych tam rozważań wymagał podziału części na trzy ,sekcje problemowe”, w które ujęto rozdziały traktujące o literaturze, ideologii i kwestiach językowo-etnicznych. Katalog problemów omówionych w tej części monografii jest bardzo szeroki. Są tam rozważania o recepcji postaci Aleksandra Wielkiego w literaturze ludowej i popularnej (Katerina Mladenovska-Ristovska, 
Krzysztof Usakiewicz), studia nad stanowiskiem historiografii oświeceniowej (Sanja Roić, Wojciech Sajkowski, Maciej Falski), jest interpretacja motywów eksploatowanych przez serbskie malarstwo historyczne (Bogdan Trifunović) i refleksje nad rozbieżnościami macedońsko-greckimi w życiu politycznym oraz edukacji historycznej (Ermis Lafazanovski, Alexandra Ioannidou, Olimpia Dragouni). W części trzeciej umieszczono również rozdziały traktujące o kulturowej charakterystyce języka macedońskiego i jego miejscu na mapie językowej Słowian (Marjan Markovik', Irena Sawicka), a także o charakterystyce etnicznej regionu - historycznej i współczesnej (Adam Balcer) i tożsamości mniejszości etnicznych - albańskiej z Macedonii oraz macedońskiej z Albanii (Rigels Halili).

Obecność wielu problemów badawczych i ich rozbicie chronologiczne tylko pozornie tworzą wrażenie, że do części drugiej recenzowanej monografii wkradł się nieład. Tymczasem zróżnicowanie tematyczne rozdziałów doskonale oddaje wieloaspektowy obraz Macedonii. Jest to obraz dynamiczny, bardziej niż może się to wydawać na podstawie znajomości historii politycznej Bałkanów. Mieni się różnorodnością idei i nawiązań. Autorzy kolejnych rozdziałów interesująco przekształcają jego odbiór, zasięg, stopień nasycenia poszczególnymi elementami charakterystycznymi. Autorzy dokonali dużego wysiłku warsztatowego i naukowego, sięgając po różnorodne materiały źródłowe. $\mathrm{Z}$ monografii wyłania się wielostronny obraz Macedonii zanurzonej w problemach wynikających z niezwykłej, nawet jak na specyfikę bałkańską, różnorodności w sferze etnicznej, religijnej i kulturowej. Prezentacje układają się w szeroką wielokierunkową narrację. Monografia jest dziełem oryginalnym, interesującym, o dużym ładunku poznawczym. Wnosi ważny wkład w rozwój studiów nad problematyką macedońską w zakresie studiów kulturoznawczych, lingwistycznych $i$ bałkanistycznych. Niewątpliwym atutem jest interdyscyplinarne ujęcie problematyki macedońskiej, na plus należy zapisać rozwagę i spokój narracji. Wszystkie zebrane w tomie studia dają obraz przekonywający, wewnętrznie powiązany, pracowicie odmalowany, stanowiący punkt wyjścia dla dalszych badań nad specyfiką regionu często określanego jako „Bałkany w pigułce”.

Jędrzej Paszkiewicz

Macedonia: Land, Region, Borderland, ed. Jolanta Sujecka, Warszawa 2013, ss. 581.

Potrzeba studiów nad wieloaspektowym problemem macedońskim jest oczywista i szukanie dla nich uzasadnienia byłoby jałowym trudem. Ma on wiele konotacji historycznych i politycznych, ale na czoło wysuwają się dwa kluczowe problemy: dziewiętnastowieczna walka środowisk macedońskich o uznanie podmiotowości i tożsamości macedońskiej oraz współczesny problem miejsca Republiki Macedonii 